\title{
Promoting Spontaneous Second Harmonic Generation through Organogelation
}

A. Belén Marco, ${ }^{\dagger}$ Fátima Aparicio, ${ }^{\S}$ Lara Faour, ${ }^{\S}$ Konstantinos Iliopoulos, ${ }^{\S}$ Yohann Morille, ${ }^{\S}$ Magali Allain, ${ }^{\S}$ Santiago Franco ${ }^{\dagger}{ }^{-}$Raquel Andreu, ${ }^{\dagger}$ Bouchta Sahraoui, ${ }^{\S}$ Denis Gindre, ${ }^{\S}$ David Canevet, ${ }^{*, \S}$ Marc Sallé ${ }^{*}, \S$

† Departamento de Química Orgánica, ICMA, Universidad de Zaragoza-CSIC, 50009 Zaragoza, Spain.

§ Laboratoire MOLTECH-Anjou, Université d'Angers, UMR CNRS 6200, 2 bd Lavoisier, 49045 Angers Cedex, France.

Contact information: david.canevet@univ-angers.fr, marc.salle@univ-angers.fr

General experimental methods $\quad$ S2

$\begin{array}{ll}\text { Synthetic details } & \mathrm{S}_{3}\end{array}$

- Synthesis and characterizations of compound $2 \quad \mathrm{~S}_{3}$

- Synthesis and characterizations of compound $3 \quad \mathrm{~S}_{4}$

- Synthesis and characterizations of compound $\mathbf{1}$ S6

- Synthesis and characterizations of compound $5 \quad \mathrm{~S}_{7}$

Table S1. Test for solubility and gel formation for compound $\mathbf{1}$ S9

Figure S1. Teas diagram and positions of the solvents under consideration as a function S10 of their Hansen solubility parameters $\delta_{\mathrm{H}}, \delta_{\mathrm{P}}$, and $\delta_{\mathrm{D}}$

Figure S2. Infrared absorption spectra of the 1-based xerogels prepared from various solvents. S10

Figure S3. X-Ray powder diffraction led on xerogels prepared from compound 1 in $\quad$ Sil various solvents.

Table S2. Optical micrographs with non-polarized or polarized light and SEM images S11

Figure S4. Detailed scheme of the SHG microscope and presentation of the device. S13

Scheme S1. Chemical structure of N,N-diethyl-4-(4-nitrophenylazo)aniline $4 \quad$ S14

Table S3. SHG and optical micrographs of the same regions as a function of the solvent $\mathrm{S}_{15}$

Figure S5. SHG images recorded for a xerogel aged for 6 months and prepared from $\quad$ S16 acetonitrile (left) and acetone (right)

Figure S6. Crystallographic structure of compound 5 observed along the a axis. S S

Figure S7. Network of hydrogen bonds observed in the X-ray crystal structure of compound $5 \quad$ S16

Figure S8. Evolution of the 'H NMR spectrum of compound 1 upon dilution in deuterated $\quad$ S17 chloroform (298 K)

Figure S9. UV-visible absorption spectrum of compound 1 


\section{General experimental methods}

\section{Chemicals}

All reagents were of commercial reagent grade and were used without further purification unless otherwise noted. Silica-gel chromatography was performed with $\mathrm{SiO}_{2}$ obtained from Sigma-Aldrich Chemistry (pore size 6o $\AA$, 40-63 $\mu$ m technical grades).

\section{Instrumentation}

NMR spectra were recorded at $298 \mathrm{~K}$ on a NMR Bruker Avance III 300 spectrometer and MALDI-TOF MS measurements were led on a MALDI-TOF Bruker Biflex III instrument or an Bruker Esquire 3000 Plus Ion Trap Mass Spectrometer using a positive-ion mode. UV-Visible absorption spectra were recorded on a Jasco $V_{73}$ spectrometer and infrared absorption spectra were measured with a Bruker Vertex 70 device. Melting points were determined with a differential scanning calorimeter (Q20 TA Instruments). Micrographs obtained with nonpolarized and polarized lights were obtained employing a Leica DM 2500P microscope and SEM images were measured with a JEOL 6301F system. The X-ray crystal structure of compound 5 was solved with an Agilent Supernova with $\mathrm{Cu}$-Koradiation $(\lambda=1.5407 \AA)$ and X-ray powder diffractograms were measured with a Bruker D8 Advance diffractometer.

\section{$\underline{\text { Gels }}$}

Critical Gelation Concentrations (CGC) were determined according to the "vial-inversion method" in miscellaneous solvents. A given amount of gelator 1 was suspended in $0.1 \mathrm{~mL}$ and heated until complete dissolution. The sample was allowed to cool to room temperature. When a gel phase was observed, solvent $(0.1 \mathrm{~mL})$ was added and the sample was submitted to another heating/cooling cycle. These operations were performed until the solvent was only partially gelled. The CGC was the last concentration allowing for complete gelation.

In order to limit the influence of the substrate, xerogels were prepared by depositing a small piece of gel $([\mathbf{1}]=1.25 \mathrm{CGC})$ on a glass slide and subsequent evaporation at room temperature. When necessary, the samples were introduced in a vacuum bell-jar in order to speed up the evaporation process. 


\section{Synthetic details}

(E)-2-(2-(Ethyl(4-((4-nitrophenyl)diazenyl)phenyl)amino)ethyl)isoindoline-1,3-Dione (2).

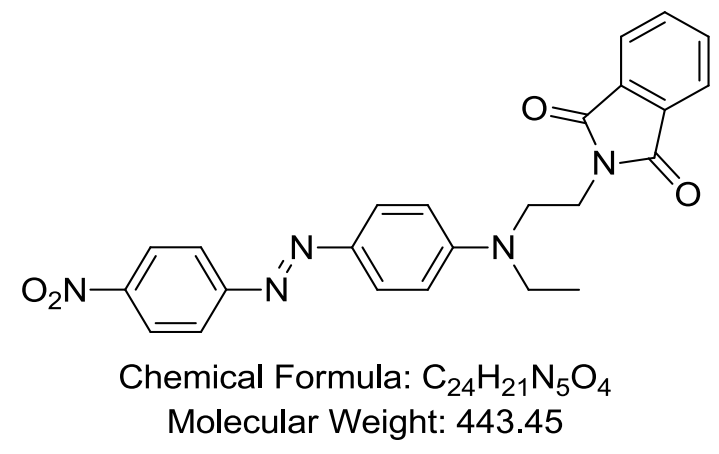

To a solution of Disperse Red 1 (2.7 g, $8.6 \mathrm{mmol})$, triphenylphosphine (3.39 g, $12.9 \mathrm{mmol})$, and phthalimide $(1.9 \mathrm{~g}, 12.9 \mathrm{mmol})$ in dry tetrahydrofuran $(100 \mathrm{~mL})$, diethylazodicarboxylate $(2 \mathrm{~mL}$, $12.9 \mathrm{mmol}$ ) was added dropwise under argon atmosphere. The reaction mixture was stirred overnight. After evaporation of the solvent, ethyl acetate was added and the resulting solid was isolated by filtration and further rinsed with ethyl acetate, affording 2 as a red solid (3.35 g, $88 \%)$.

${ }^{1} \mathrm{H}$ NMR (300 MHz, CDCl $\left.{ }_{3}\right) \delta(\mathrm{ppm}): 8.33$ (d, J=9.1 Hz, 2H, ArH), $7.92(\mathrm{~d}, J=9.1 \mathrm{~Hz}, 2 \mathrm{H}, \operatorname{ArH})$, 7.89 (d, J=9.3 Hz, 2H, ArH), 7.87-7.82 (m, 2H, ArH), 7.76-7.69 (m, 2H, ArH), 6.90 (d, J=9.3 Hz, $2 \mathrm{H}, \mathrm{ArH}), 3.95\left(\mathrm{t}, 2 \mathrm{H}, J=7.8 \mathrm{~Hz}, 2 \mathrm{H}, \mathrm{CH}_{2} \mathrm{~N}\right), 3.68\left(\mathrm{t}, 2 \mathrm{H}, J=7.8 \mathrm{~Hz}, \mathrm{NCH}_{2}\right), 3.56(\mathrm{q}, J=7.3 \mathrm{~Hz}, 2 \mathrm{H}$, $\left.\mathrm{NCH}_{2}\right), 1.27\left(\mathrm{t}, J=7.3 \mathrm{~Hz}, 3 \mathrm{H}, \mathrm{CH}_{3}\right) .{ }^{13} \mathrm{C} \mathrm{NMR}\left(75 \mathrm{MHz}, \mathrm{CDCl}_{3}\right) \delta(\mathrm{ppm}): 168.1,156.7,151.1,147.4$, 143.9, 134.2, 131.9, 126.3, 124.6, 123.4, 122.6, 111.5, 47.9, 45.3, 34.9, 12.4. IR (ATR) cm $\mathrm{cm}^{-1}: 1712(\mathrm{C}=\mathrm{O})$, $1596(\mathrm{C}=\mathrm{C}$ Ar $), 1515\left(-\mathrm{NO}_{2}\right), 1326\left(-\mathrm{NO}_{2}\right) . \mathrm{MS}\left(\mathrm{MALDI}^{+}\right) \mathrm{m} / \mathrm{z}: 444.2[\mathrm{M}+\mathrm{H}]^{+} . \mathrm{m} \cdot \mathrm{p} \cdot 182-183^{\circ} \mathrm{C}$

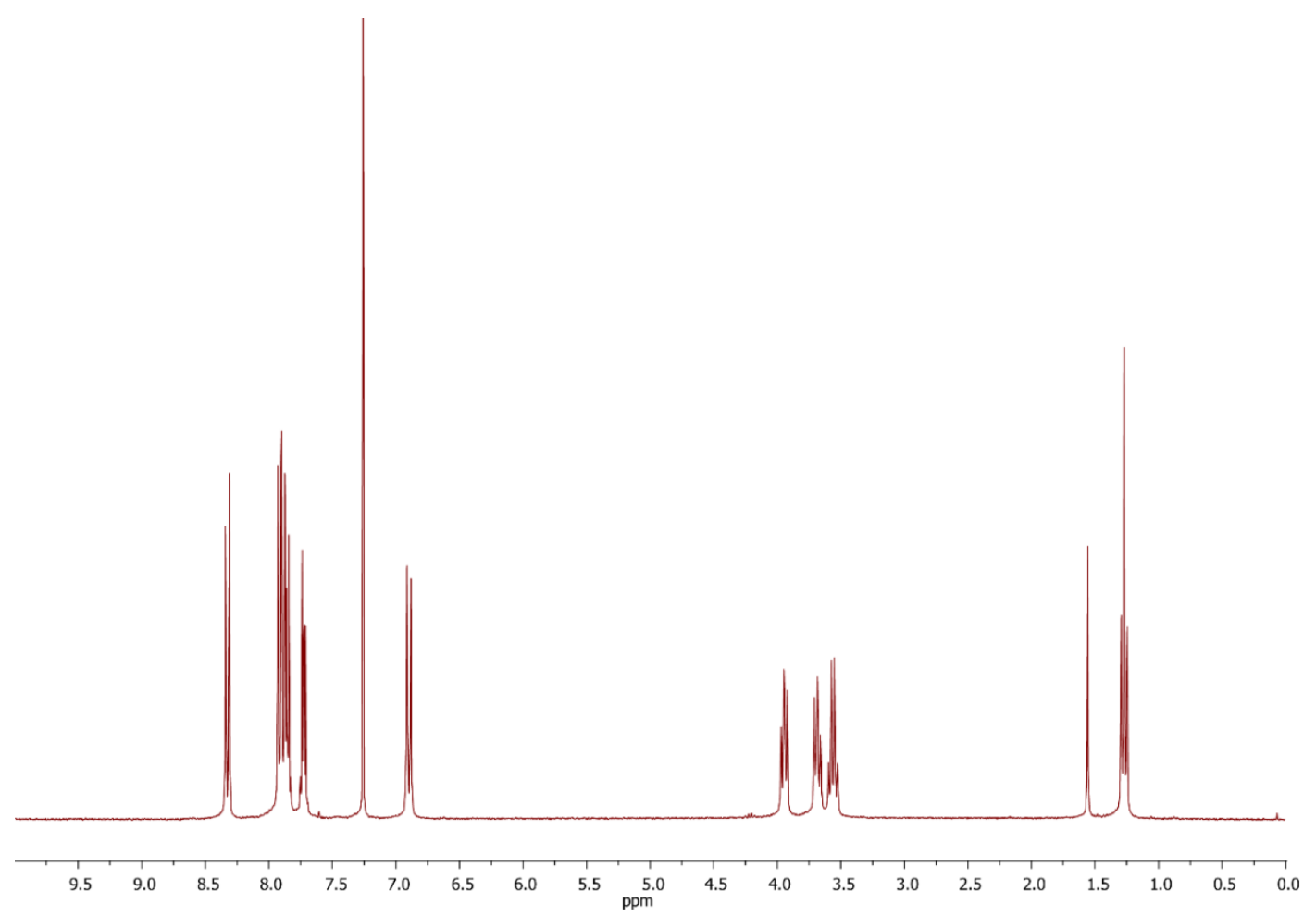

${ }^{1} \mathrm{H}$ NMR spectrum of compound $2\left(\mathrm{CDCl}_{3}, 300 \mathrm{MHz}, 298 \mathrm{~K}\right)$. 


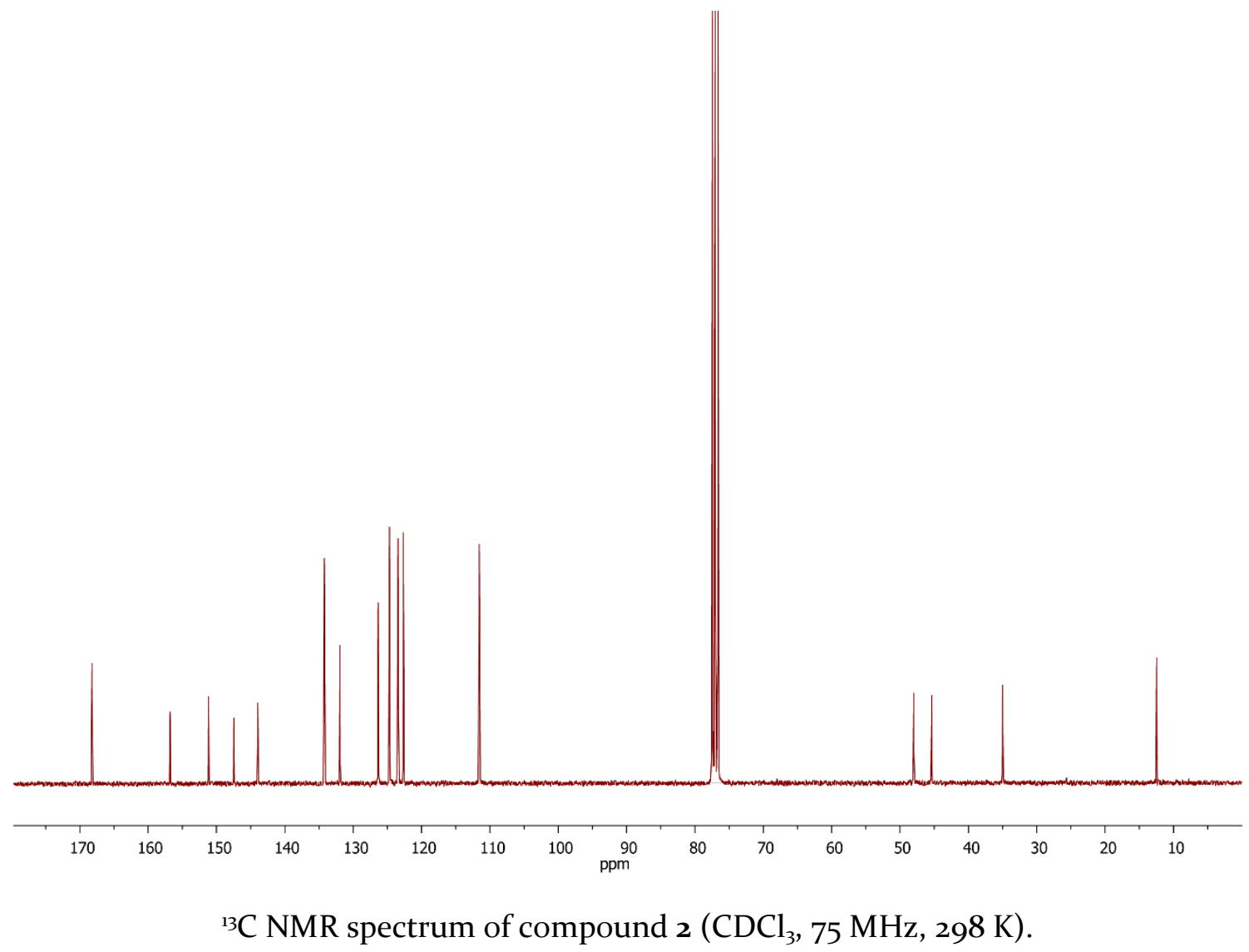

(E)- $N^{I}$-Ethyl- $N^{I}$-(4-((4-nitrophenyl)diazenyl)phenyl)ethane-1,2-diamine (3).

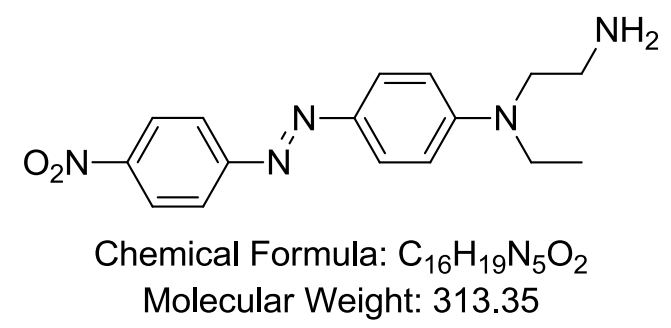

To a solution of compound $2(1.52 \mathrm{~g}, 3.45 \mathrm{mmol})$ in absolute $\mathrm{EtOH}(120 \mathrm{~mL})$, an aqueous solution of methylamine ( $40 \%, 16.1 \mathrm{~mL}, 206 \mathrm{mmol})$ was added dropwise, and the mixture was refluxed overnight at $85^{\circ} \mathrm{C}$. The reaction mixture was allowed to cool at room temperature and the solvent was evaporated. Water was added $(5 \mathrm{~mL})$ and $\mathrm{pH}$ was tuned to 13 by adding $\mathrm{NaOH} 1 \mathrm{M}$ $(50 \mathrm{~mL})$. The resulting suspension was filtered and extracted with ethyl acetate. After evaporation of the solvent, the obtained red solid was dried under vacuum at $45^{\circ} \mathrm{C}$ and was used in the next step without further purification.

${ }^{1} \mathrm{H}$ NMR (300 MHz, CDCl $) \delta(\mathrm{ppm}): 8.33(\mathrm{~d}, J=9.1 \mathrm{~Hz}, 2 \mathrm{H}, \mathrm{ArH}), 7.92(\mathrm{~d}, J=9.1 \mathrm{~Hz}, 2 \mathrm{H}, \operatorname{ArH})$, $7.89(\mathrm{~d}, J=9.2 \mathrm{~Hz}, 2 \mathrm{H}, \mathrm{ArH}), 6.79(\mathrm{~d}, J=9.2 \mathrm{~Hz}, 2 \mathrm{H}, \mathrm{ArH}), 3.55\left(\mathrm{q}, 2 \mathrm{H}, J=7.0 \mathrm{~Hz}, 2 \mathrm{H}, \mathrm{CH}_{2} \mathrm{~N}\right), 3.50$ $\left(\mathrm{t}, 2 \mathrm{H}, J=6.9 \mathrm{~Hz}, \mathrm{NCH}_{2}\right), 3.01\left(\mathrm{t}, J=6.9 \mathrm{~Hz}, 2 \mathrm{H}, \mathrm{NCH}_{2}\right), 1.25\left(\mathrm{t}, J=7.0 \mathrm{~Hz},{ }_{3} \mathrm{H}, \mathrm{CH}_{3}\right) .{ }^{13 \mathrm{C}} \mathrm{NMR}(75$ MHz, DMSO-d 6 ) $\delta$ (ppm): 156.2, 151.7, 146.6, 142.4, 126.1, 124.8, 122.3, 111.3, 52.9, 44.9, 12.1. IR (ATR) $\mathrm{cm}^{-1}: 3381(-\mathrm{NH}), 1583\left(\mathrm{C}=\mathrm{C}\right.$ Ar), $1512\left(-\mathrm{NO}_{2}\right), 1323\left(-\mathrm{NO}_{2}\right)$. MS $\left(\mathrm{MALDI}^{+}\right) \mathrm{m} / \mathrm{z}: 314.3$ $[\mathrm{M}+\mathrm{H}]^{+}$. m.p. $102-104^{\circ} \mathrm{C}$ 


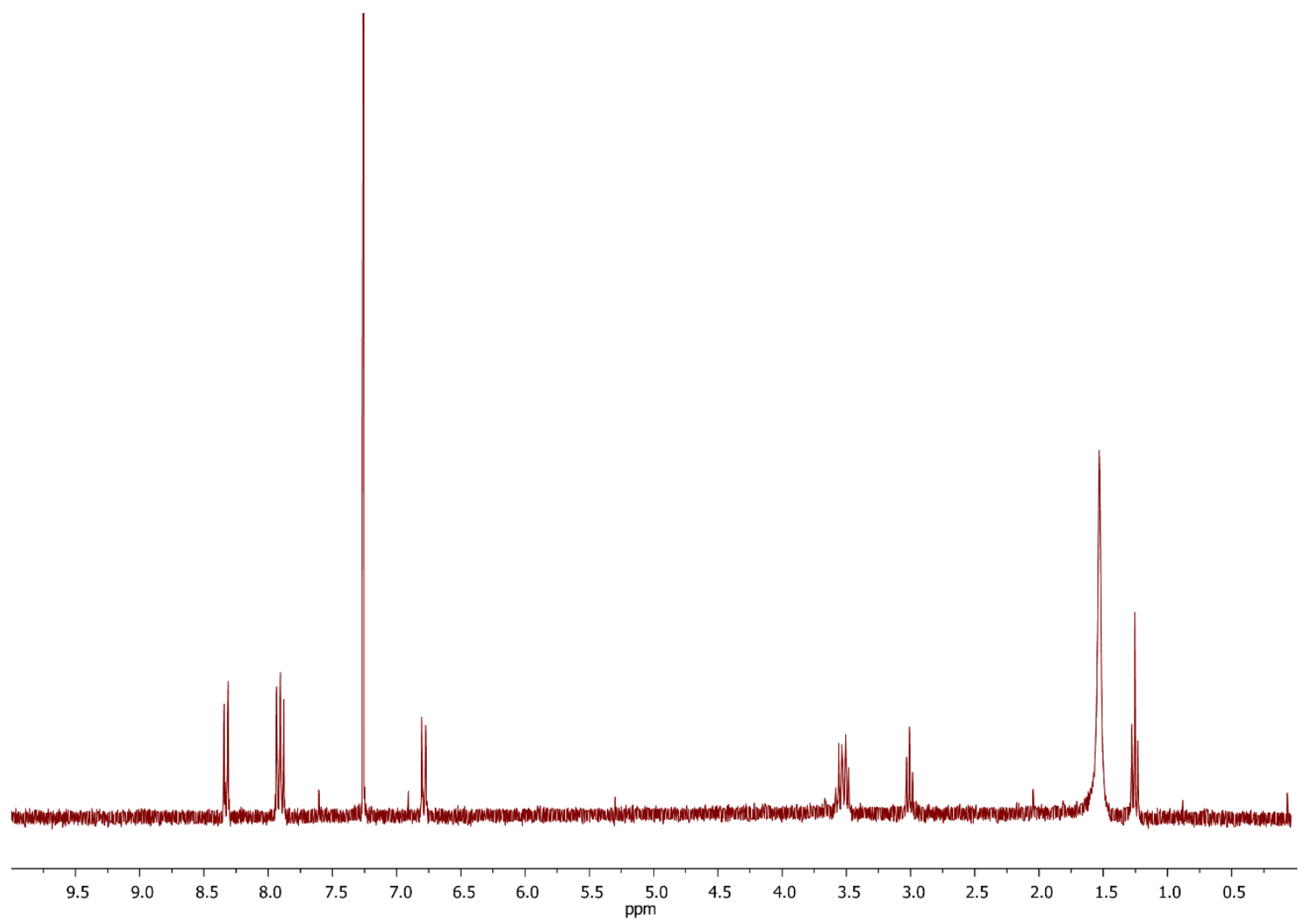

${ }^{1} \mathrm{H}$ NMR spectrum of compound $3\left(\mathrm{CDCl}_{3}, 300 \mathrm{MHz}, 298 \mathrm{~K}\right)$.

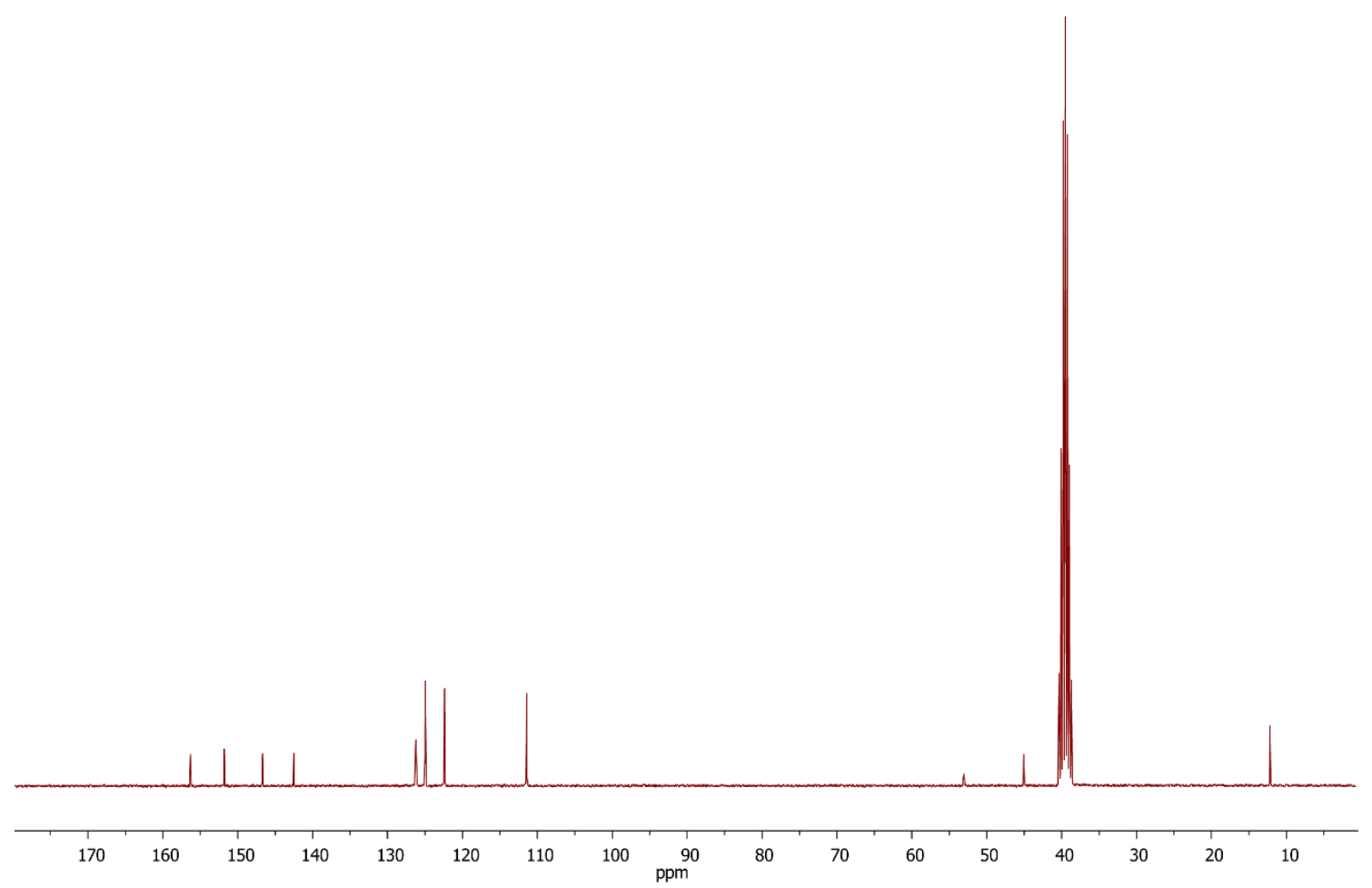

${ }^{13} \mathrm{C}$ NMR spectrum of compound 3 (DMSO-d 6 , $75 \mathrm{MHz}, 298 \mathrm{~K}$ ). 
(E)-1-Dodecyl-3-(2-((4-((4-nitrophenyl)diazenyl)phenyl)amino)ethyl)urea (1).<smiles>CCCCCCCCCCCCNC(=O)NCCN(CC)c1ccc(N=Nc2ccc([N+](=O)[O-])cc2)cc1</smiles>

Chemical Formula: $\mathrm{C}_{29} \mathrm{H}_{44} \mathrm{~N}_{6} \mathrm{O}_{3}$ Molecular Weight: 524.70

To a solution of 3 ( $0.51 \mathrm{~g}, 1.63 \mathrm{mmol})$ in dry dichloromethane $(60 \mathrm{~mL})$, dodecylisocyanate (o.59 $\mathrm{mL}, 2.44 \mathrm{mmol}$ ) was added dropwise under argon atmosphere, and the mixture was stirred overnight. After evaporation of the solvent, the residue was precipitated in chloroform/pentane affording 1 as a red solid ( $0.652 \mathrm{~g}, 76 \%)$.

${ }^{1} \mathrm{H}$ NMR (300 MHz, $\mathrm{CDCl}_{3}$ ) $\delta$ (ppm): 8.33 (d, J=9.1 Hz, 2H, ArH), 7.91 (d, J=9.1 Hz, 2H, ArH), 7.88 (d, J=9.2 Hz, $2 \mathrm{H}, \mathrm{ArH}$ ), 6.83 (d, J=9.2 Hz, 2H, ArH), 4.40 (br, $1 \mathrm{H}, \mathrm{NH}$ ), 4.21 (br, $1 \mathrm{H}, \mathrm{NH}$ ), 3.59 (t, $\left.J=6.5 \mathrm{~Hz}, 2 \mathrm{H}, \mathrm{NCH}_{2}\right), 3.53\left(\mathrm{t}, J=7.1 \mathrm{~Hz}, 2 \mathrm{H}, \mathrm{NCH}_{2}\right) 3.45\left(\mathrm{t}, J=6.5 \mathrm{~Hz}, 2 \mathrm{H}, \mathrm{CH}_{2} \mathrm{~N}\right), 3.13(\mathrm{q}, J=6.2$ $\left.\mathrm{Hz}, 2 \mathrm{H}, \mathrm{NCH}_{2}\right)$, 1.53-1.41 (m, $\left.2 \mathrm{H}, \mathrm{CH}_{2}\right), 1.35-1.17\left(\mathrm{br}, 18 \mathrm{H},\left(\mathrm{CH}_{2}\right)_{9}\right), 0.87\left(\mathrm{t}, J=6.6 \mathrm{~Hz}, 6 \mathrm{H}, \mathrm{CH}_{3}\right) .{ }^{13} \mathrm{C}$ NMR (75 MHz, DMSO-d ${ }^{6}$ ) $\delta$ (ppm): 158.1, 156.2, 151.8, 146.6, 142.5, 126.0, 124.8, 122.3, 111.4, 49.7, 44.7, 37.0, 31.2, 30.6, 29.9, 28.9, 28.7, 28.6, 28.3, 22.0, 13.8, 12.0. IR (ATR) cm $\mathrm{cm}^{-1}: 3353$ (-NH), 1733 $(\mathrm{C}=\mathrm{O}), 1633(\mathrm{C}=\mathrm{O}), 1606(\mathrm{C}=\mathrm{C} \mathrm{Ar}), 1506\left(-\mathrm{NO}_{2}\right), 1343\left(-\mathrm{NO}_{2}\right)$. HRMS $\left(\mathrm{ESI}^{+}\right)$calcd. for $\mathrm{C}_{29} \mathrm{H}_{44} \mathrm{~N}_{6} \mathrm{O}_{3}\left[\mathrm{M}^{+\cdot}\right]$, 524.3475; found, 524.3494. m.p. $153-155^{\circ} \mathrm{C}$

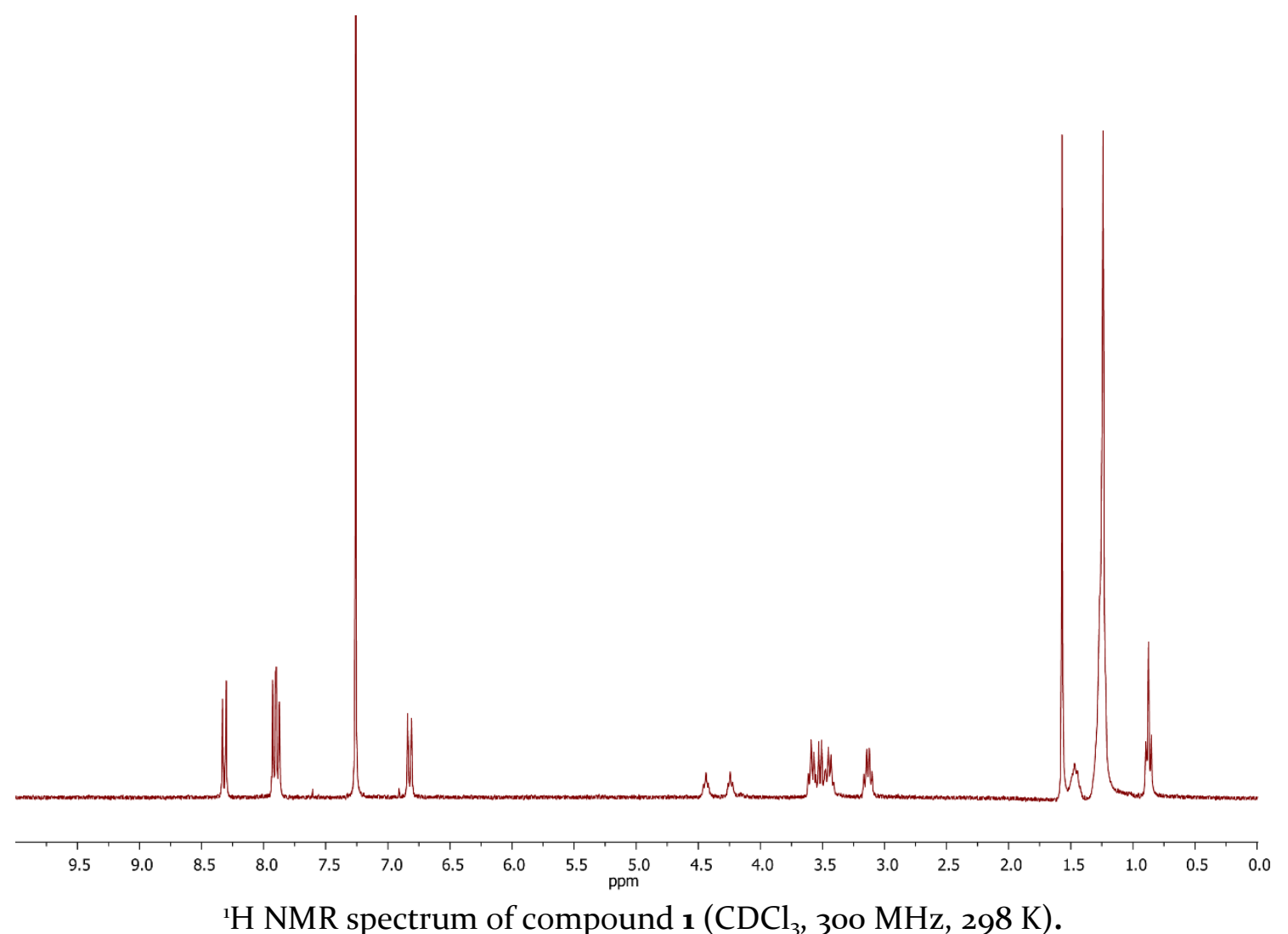




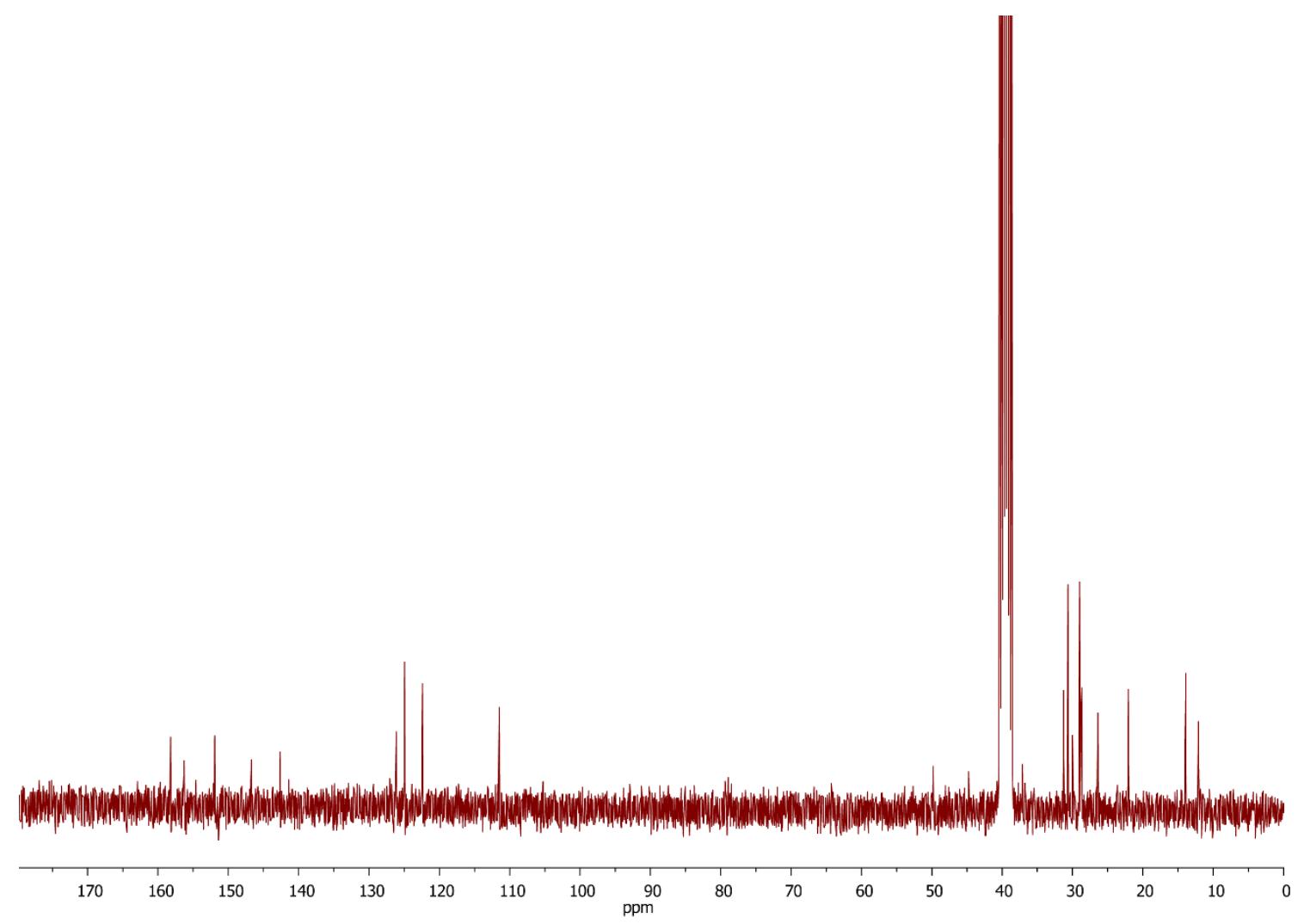

${ }^{13} \mathrm{C}$ NMR spectrum of compound $\mathbf{1}\left(\mathrm{DMSO}^{\mathrm{d}} \mathrm{d}^{6}, 75 \mathrm{MHz}, 298 \mathrm{~K}\right)$.

(E)-1-Octyl-3-(2-((4-((4-nitrophenyl)diazenyl)phenyl)amino)ethyl)urea (5).<smiles>CCCCCCCCNC(=O)NCCN(CC)c1ccc(N=Nc2ccc([N+](=O)[O-])cc2)cc1</smiles>

Chemical Formula: $\mathrm{C}_{25} \mathrm{H}_{36} \mathrm{~N}_{6} \mathrm{O}_{3}$

Molecular Weight: 468.59

To a solution of amine 3 (70 $\mathrm{mg}, 0.15 \mathrm{mmol}$ ) in dry dichloromethane (10 $\mathrm{mL})$, octylisocyanate (30 mg, $0.18 \mathrm{mmol}, 1.2 \mathrm{eq}$.) was added dropwise under argon atmosphere, and the mixture was stirred overnight. After evaporation of the solvent, the residue was precipitated in chloroform/pentane affording 5 as a red solid ( $57 \mathrm{mg}, 81 \%)$.

${ }^{1} \mathrm{H}$ NMR (300 MHz, CDCl $) \delta(\mathrm{ppm}): 8.32(\mathrm{~d}, J=9.0 \mathrm{~Hz}, 2 \mathrm{H}, \operatorname{ArH}), 7.91(\mathrm{~d}, J=9.1 \mathrm{~Hz}, 2 \mathrm{H}, \operatorname{ArH})$, 7.88 (d, J=9.1 Hz, 2H, ArH), $6.82(\mathrm{~d}, J=9.2 \mathrm{~Hz}, 2 \mathrm{H}, \mathrm{ArH}), 4.44(\mathrm{t}, J=5.7 \mathrm{~Hz}, 1 \mathrm{H}, \mathrm{NH}), 4.21$ (t, $J=5.4$ $\mathrm{Hz}, 1 \mathrm{H}, \mathrm{NH}), 3.58\left(\mathrm{~m}, 2 \mathrm{H}, \mathrm{NCH}_{2}\right), 3.52\left(\mathrm{~m}, 2 \mathrm{H}, \mathrm{NCH}_{2}\right) 3.44\left(\mathrm{~m}, 2 \mathrm{H}, \mathrm{CH}_{2} \mathrm{~N}\right), 3.13(\mathrm{q}, J=6.6 \mathrm{~Hz}$, $\left.2 \mathrm{H}, \mathrm{NCH}_{2}\right)$, $1.47\left(\mathrm{~m}, 2 \mathrm{H}, \mathrm{CH}_{2}\right), 1.34-1.22\left(\mathrm{br}, 10 \mathrm{H},\left(\mathrm{CH}_{2}\right)_{5}\right), 0.87\left(\mathrm{~m}, 6 \mathrm{H}, 2 \times \mathrm{CH}_{3}\right)$.

${ }^{13} \mathrm{C} \mathrm{NMR}\left(75 \mathrm{MHz}, \mathrm{CDCl}_{3}\right) \delta$ (ppm): 158.2, 157.0, 153.0, 151.7, 147.5, 143.8, 126.5, 124.8, 122.8, 111.5, 50.3, 45.7, 40.9, 38.4, 31.9, 30.3, 29.4, 29.3, 27.0, 22.8, 14.2, 12.4. IR (ATR) $\mathrm{cm}^{-1}: 3323(-\mathrm{NH}), 1624$ $(\mathrm{C}=\mathrm{O}), 1583\left(\mathrm{C}=\mathrm{C}\right.$ Ar), $1511\left(-\mathrm{NO}_{2}\right), 1352\left(-\mathrm{NO}_{2}\right)$. HRMS (FAB) calcd. for $\mathrm{C}_{25} \mathrm{H}_{36} \mathrm{~N}_{6} \mathrm{O}_{3}\left[\mathrm{M}^{+\cdot}\right]$, 468.2848; found, 468.2851 . m.p. $164-166^{\circ} \mathrm{C}$. 

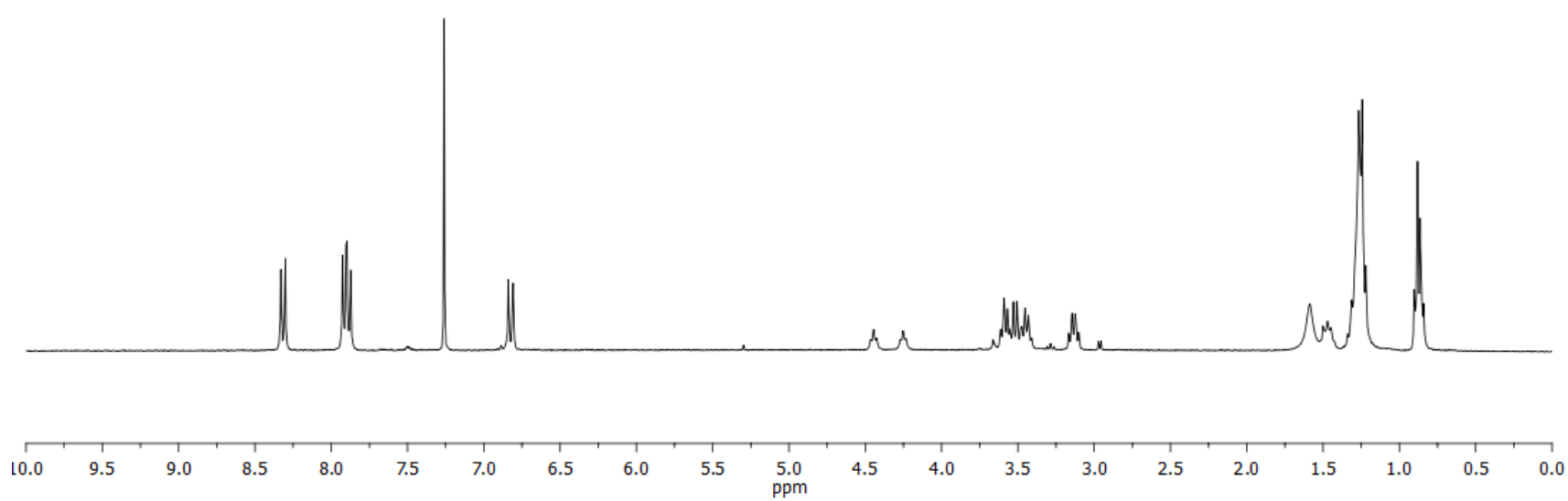

${ }^{1} \mathrm{H}$ NMR spectrum of compound $\mathbf{5}\left(\mathrm{CDCl}_{3}, 300 \mathrm{MHz}, 298 \mathrm{~K}\right)$.

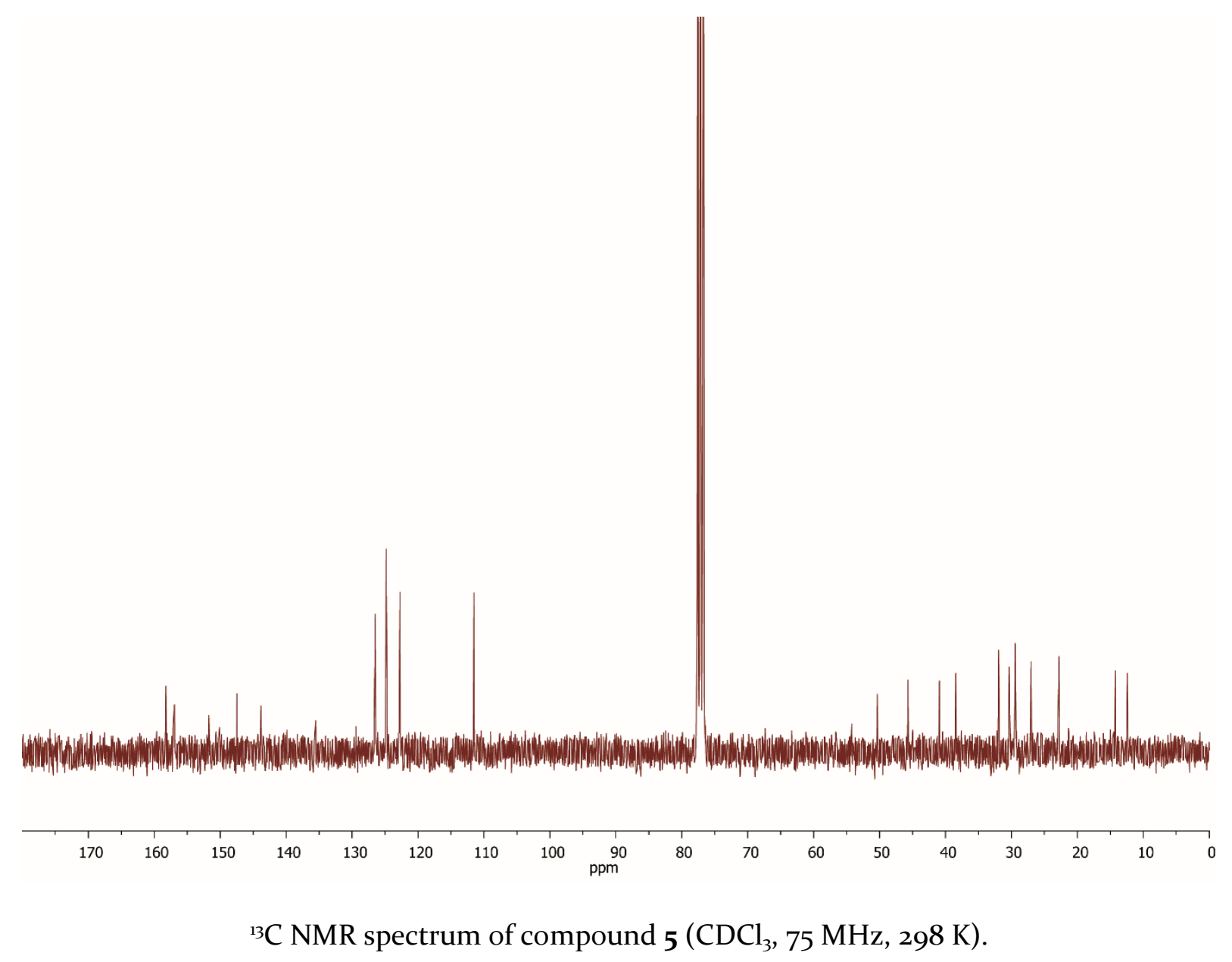


Table S1. Test for solubility and gel formation for compound $\mathbf{1}-\mathrm{P}$ stands for precipitate, NS for Non Soluble, G for gel, CGC for Critical Gelation Concentration and GN for Gelation Number $\left(\mathrm{GN}=1000 \mathrm{x} \mathrm{d}_{\text {solvent }} \mathrm{x} \mathrm{M}_{\text {gelator }} / \mathrm{CGC}\left(\mathrm{g} \cdot \mathrm{L}^{-1}\right) \times \mathrm{M}_{\text {solvent }}\right)$. The gelation number corresponds to the number of gelled solvent molecules per gelator molecule.

\begin{tabular}{|c|c|c|c|c|}
\hline Solvent & $\mathrm{NS} / \mathrm{P} / \mathrm{G}$ & CGC $\left(g . L^{-1}\right)$ & CGC $\left(\mathrm{mmol} . \mathrm{L}^{-1}\right)$ & GN \\
\hline Acetone & G & 13.6 & $25 \cdot 9$ & 525 \\
\hline Acetonitrile & G & 10.0 & 19.1 & 1004 \\
\hline Chloroform & $\mathrm{P}$ & -- & -- & -- \\
\hline Ethyl acetate & $P$ & -- & -- & -- \\
\hline Dimethylformamide & $\mathrm{P}$ & -- & -- & -- \\
\hline Tetrachloromethane & NS & -- & -- & -- \\
\hline Chlorobenzene & G & 18.0 & $34 \cdot 3$ & 287 \\
\hline o-Dichlorobenzene & G & 50.0 & $95 \cdot 3$ & 93 \\
\hline 1,2,4-Trichlorobenzene & G & 19.4 & 37.0 & 216 \\
\hline Hexadecane & NS & -- & -- & -- \\
\hline Cyclohexane & NS & -- & -- & -- \\
\hline p-Xylene & G & 13.8 & 26.3 & 308 \\
\hline Toluene & G & 14.2 & 27.1 & 348 \\
\hline 1,4-Dioxane & G & $15 \cdot 4$ & 29.4 & 400 \\
\hline Tetrahydrofurane & $\mathrm{P}$ & -- & -- & -- \\
\hline Propan-2-ol & $\mathrm{P}$ & -- & -- & -- \\
\hline Octan-1-ol & G & 33.2 & 63.3 & 100 \\
\hline
\end{tabular}



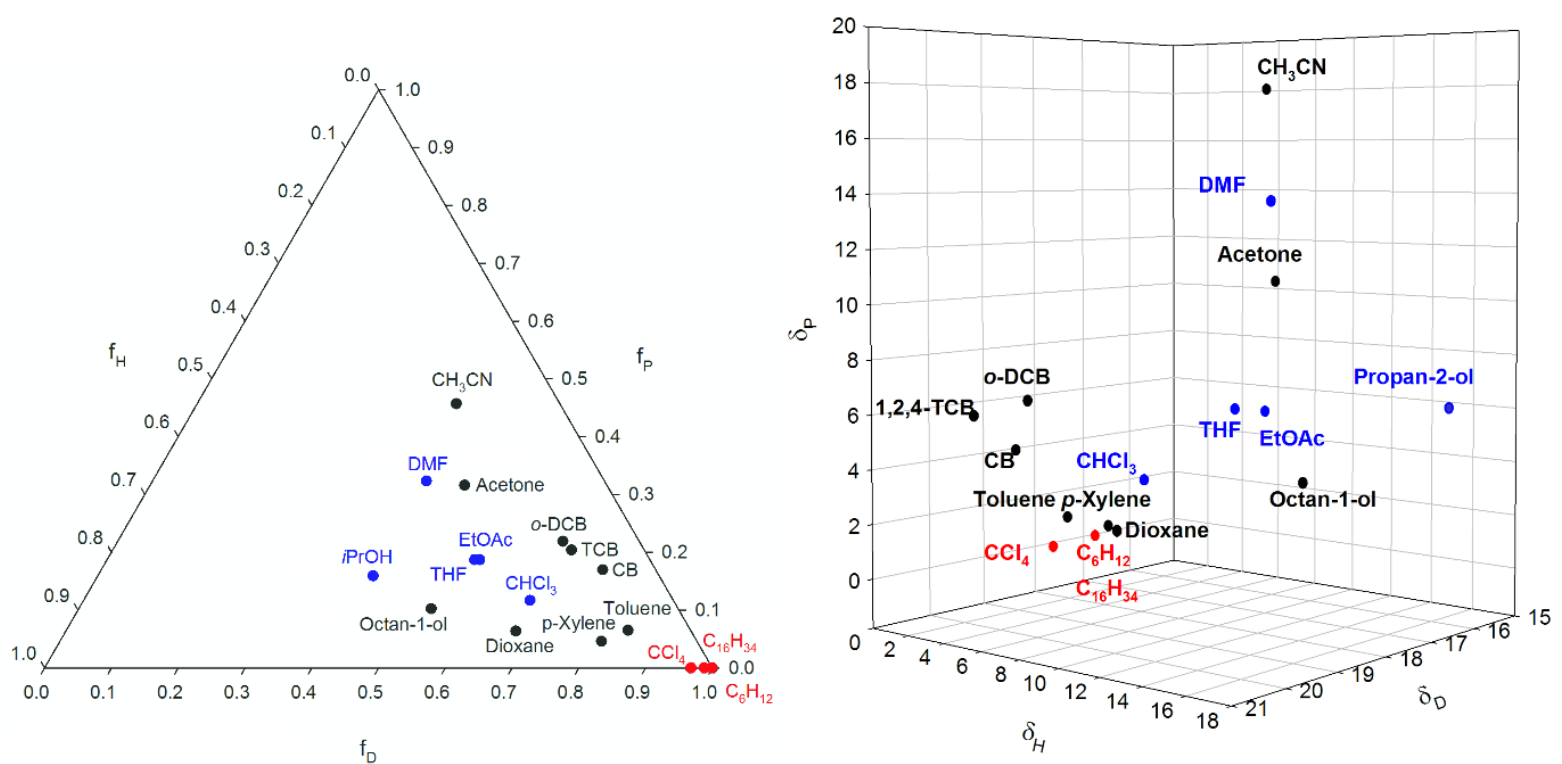

Figure S1. Teas diagram (left) and positions of the solvents under consideration as a function of their Hansen solubility parameters $\delta_{\mathrm{H}}, \delta_{\mathrm{P}}$, and $\delta_{\mathrm{D}}\left(\right.$ in $\left.\mathrm{MPa}^{1 / 2}\right)$, which indicate their ability to interact through hydrogen bonds, polar interactions and dispersion forces, respectively. $f_{H}, f_{P}$ and $f_{D}$ are calculated according to the following formula:

$$
f_{H}=\frac{\delta_{H}}{\delta_{H}+\delta_{P}+\delta_{D}} \quad f_{D}=\frac{\delta_{D}}{\delta_{H}+\delta_{P}+\delta_{D}} \quad f_{P}=\frac{\delta_{P}}{\delta_{H}+\delta_{P}+\delta_{D}}
$$

Colors have the following meaning: blue for precipitation, black for gelation and red for insoluble upon heating.

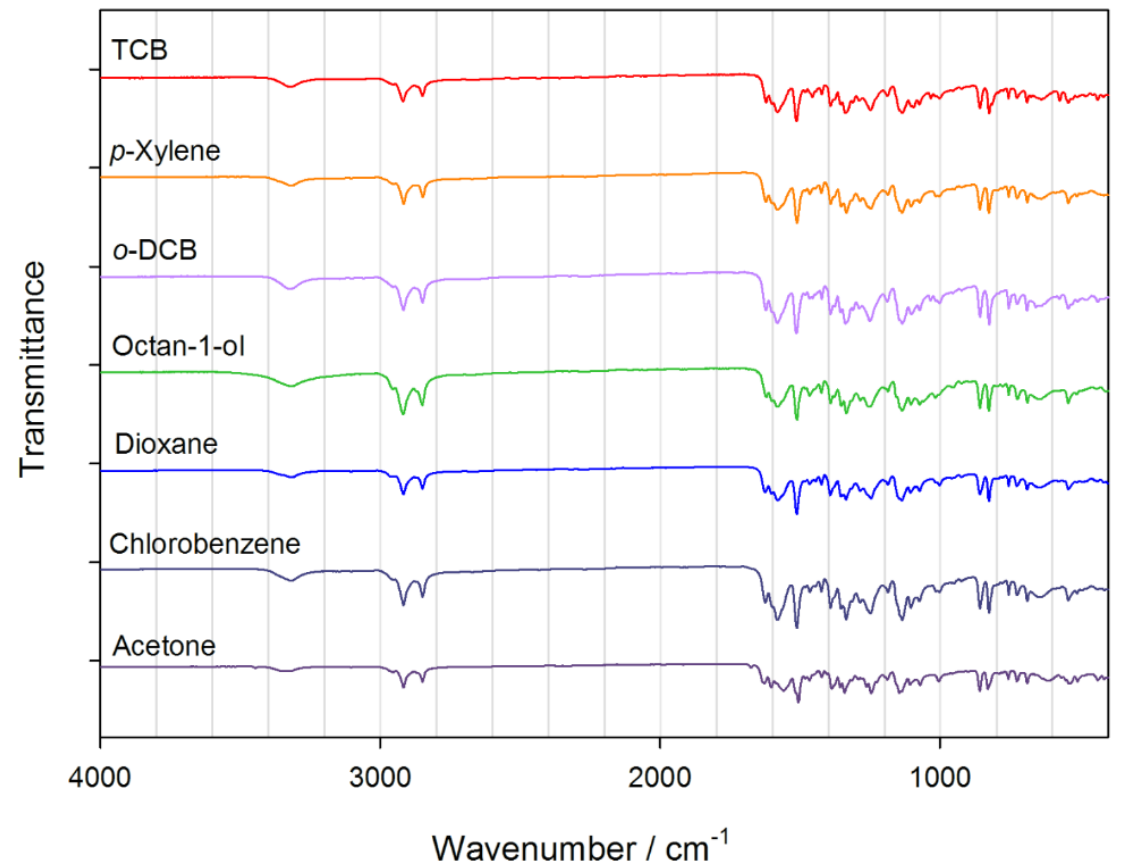

Figure S2. Infrared absorption spectra of the 1-based xerogels prepared from various solvents. 


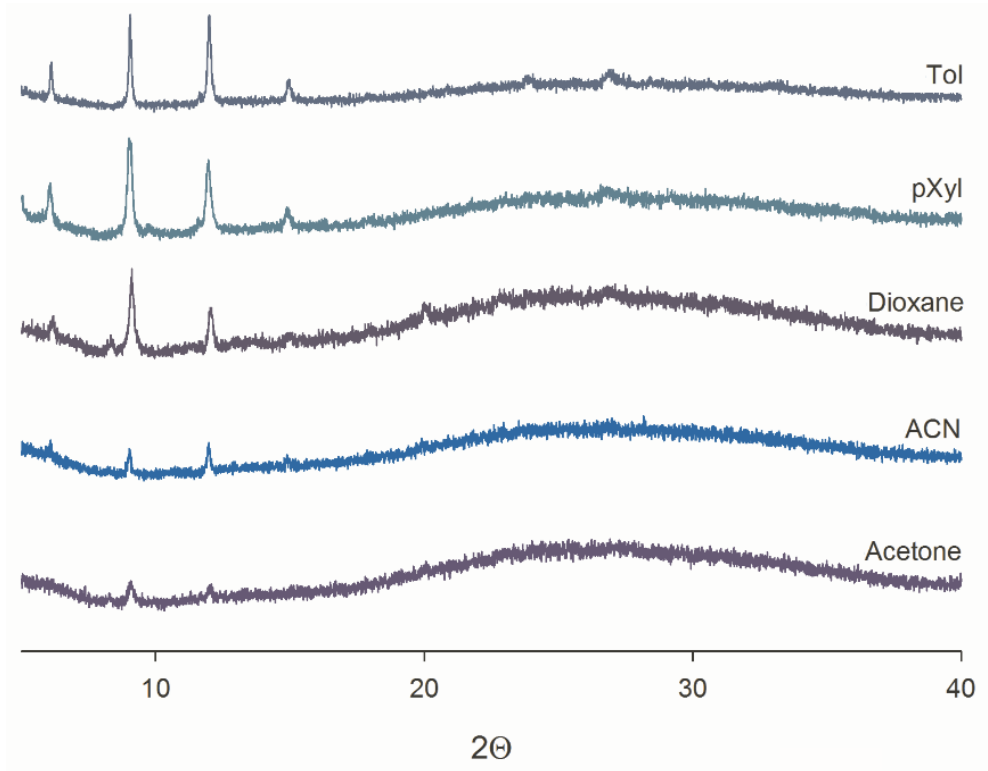

Figure $S_{3}$. X-Ray powder diffraction led on xerogels prepared from compound $\mathbf{1}$ in various solvents. Tol stands for toluene, $\mathrm{pXyl}$ for $p$-xylene and ACN for acetonitrile.

Table S2. Optical micrographs with non-polarized or polarized light and SEM images recorded after depositing a piece of gel on a glass slide and subsequent evaporation of the solvent

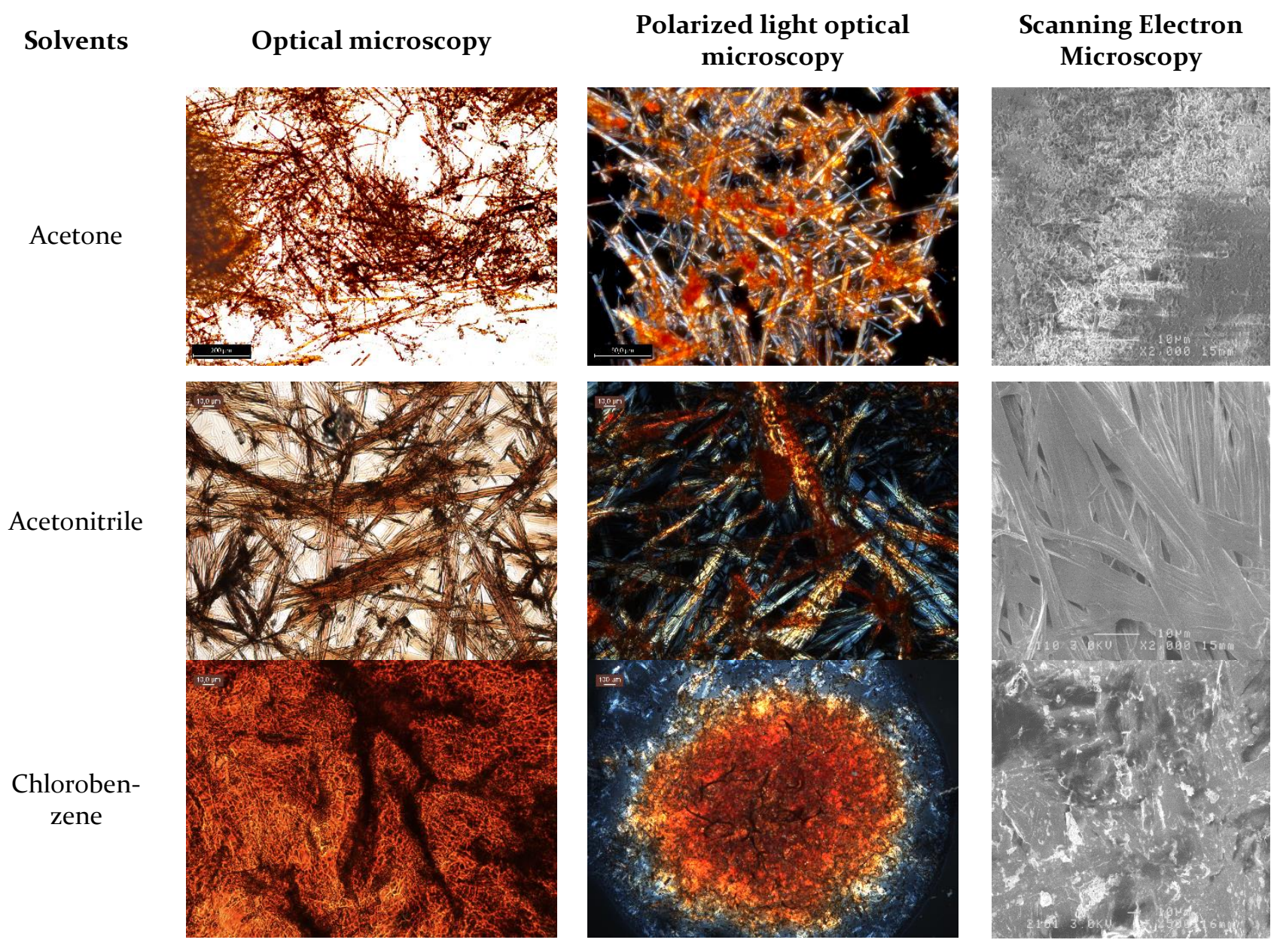




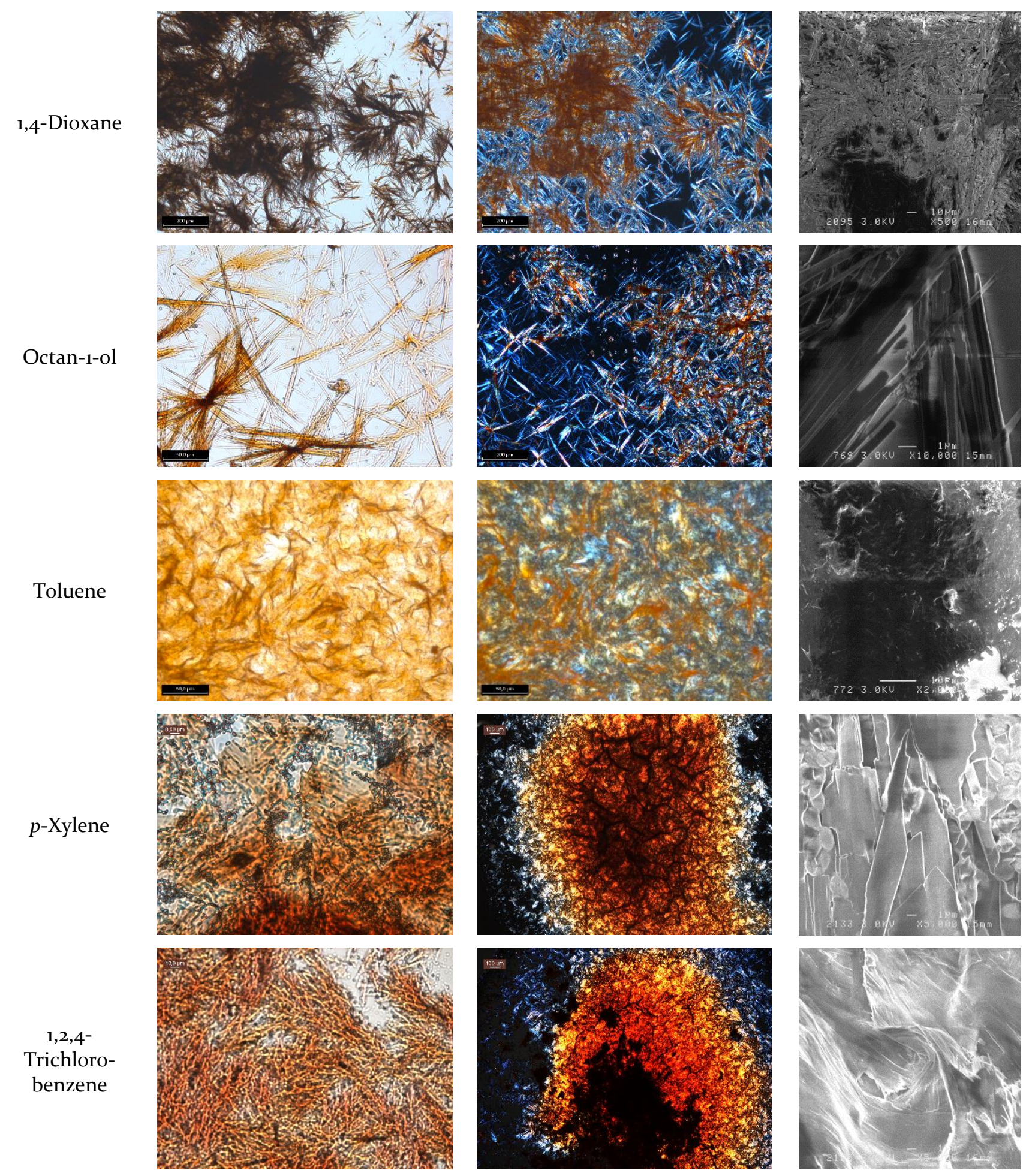




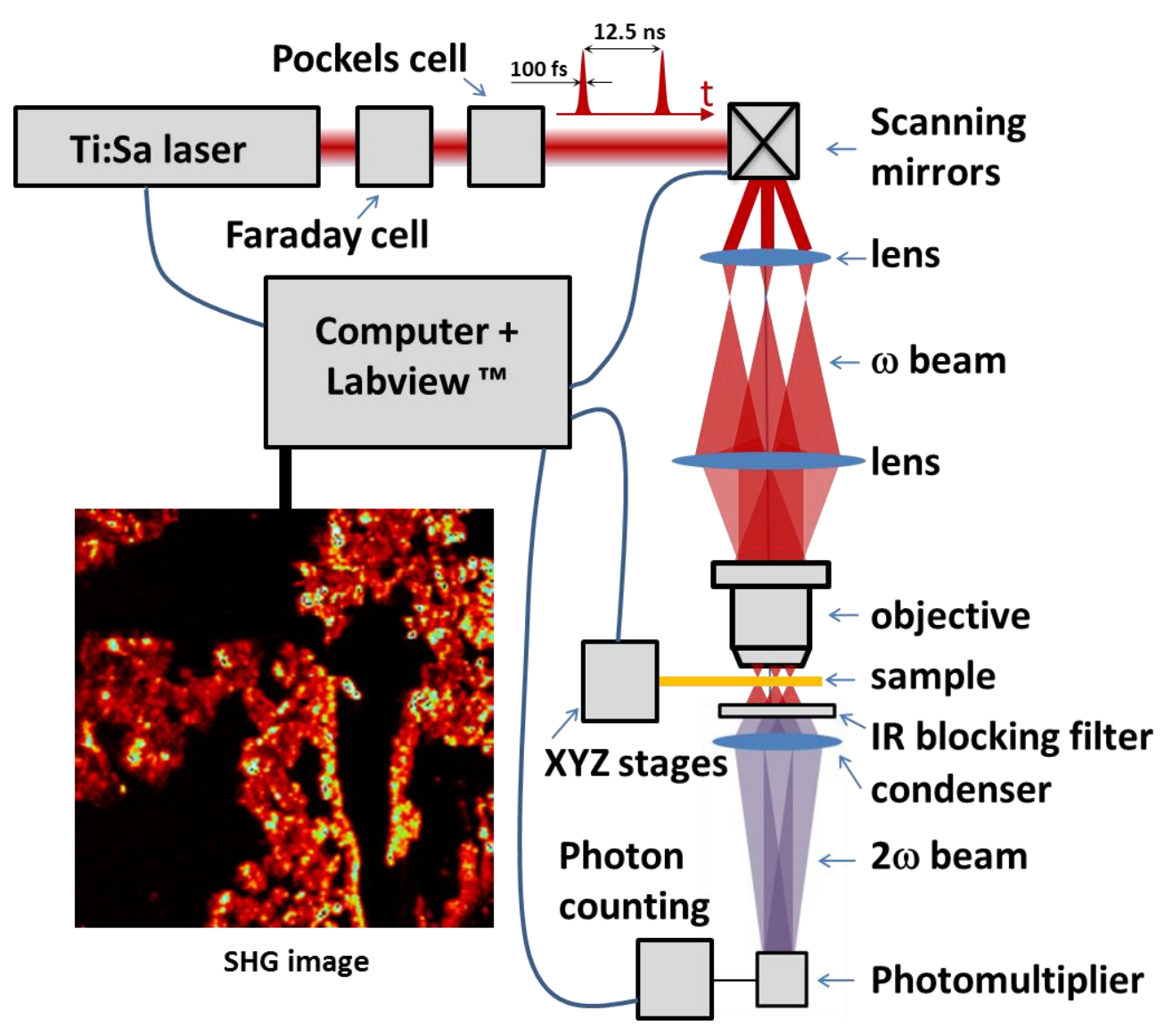

Figure $\mathbf{S}$. Detailed scheme of the SHG microscope.

The 2nd order NLO properties of the compounds were investigated employing the SHG scanning microscopy setup presented in Figure $\mathrm{S}_{4}$. Two or three-dimensional mapping of the SHG signal can be measured by employing two galvanometric mirrors controlling the displacement of the laser on the samples. The focused laser beam displays a pulse duration of $100 \mathrm{fs}$ and a repetition rate of $8 \mathrm{o} \mathrm{MHz}$. The SHG signal is detected with of a photon counter coupled with a fast photomultiplier. The laser beam scans a selected area of the sample and the SHG response is acquired point-by-point. The SHG intensity measured for each point is stored and will eventually constitute a pixel of the SHG image (typically $200 x 200$ pixels). The laser power was adjusted to $60 \mathrm{~mW}$, the laser wavelength was $800 \mathrm{~nm}$ and the pixeltime was $20 \mu \mathrm{sec}$. The laser source is a Ti:Sapphire (Tsunami, Spectra Physics). Note that the photons emitted by the SHG process show a wavelength about $400 \mathrm{~nm}$, which corresponds to a low absorption spectral window of the samples (see Figure S9). The pump laser is a 1o W solid-state laser (Millenia Xs, Spectra Physics). The angular deviation of the beam was controlled with an X-Y scanner (Cambridge Technology). The laser power was adjusted by means of an electro-optic modulator (Pockels cell). A Faraday rotator was used as an optical isolator. The beam was focused on the sample with an x10 objective lens (Olympus, N.A. $=0.25$ ). The SHG signal is filtered with an IR blocking filter (NT48-071, Edmund Optics and BG39, Schott) and detected with a photomultiplier $\left(\mathrm{H}_{744} \mathrm{P}-40\right.$, Hamamatsu) and a photon counter (C9744, Hamamatsu). The samples were deposited on glass slides and placed on XYZ motorized stages (Newport) controlled by an 8 axes motion controller/ Driver (XPS, Newport). The light polarization, the voltage control of the galvanometric mirrors and the micropositioning of the sample are precisely piloted by means of a homemade National Instrument 
Labview $^{\mathrm{TM}}$ program. This program is used to store the signal for each position of the scanned laser beam on the sample and to construct the SHG images.

Determining the spatial resolution of the NLO process and hence, the elementary volume of ellipsoidal shape (voxel) in which the non-linear optical process efficiently occurs, is of interest. This resolution can be calculated using the distribution function of the square of the Illumination Point Spread Function. ${ }^{1}$ By adjusting a Gaussian function with the lateral and axial profiles IPSF2, ${ }^{2}$ the lateral resolution $\omega x y$ and axial $\omega z$ of the voxel can be determined. For the microscope objective under consideration (N.A. $=0.25$ ), the expressions are:

$$
\omega_{z}=\frac{0.532 \lambda}{\sqrt{2}}\left(\frac{1}{n-\sqrt{n^{2}-N A^{2}}}\right), \quad \omega_{x y}=\frac{0.32 \lambda}{\sqrt{2} \times N A}
$$

And the excitation volume is given by:

$$
V=\frac{\pi^{3 / 2}}{\omega_{x y}^{2} \omega_{z}}
$$

In this manner, the excitation volume calculated for our experiment is $74 \mu \mathrm{m}^{3}$.

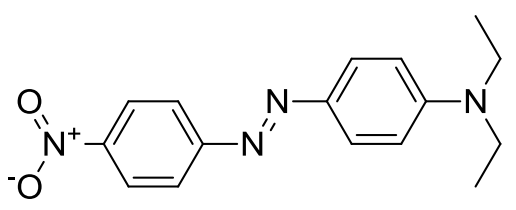

Scheme S1. Chemical structure of N,N-diethyl-4-(4-nitrophenylazo)aniline 4 . 
Table S3. SHG and optical micrographs (identical scales) of the same regions as a function of the solvent. Samples were studied 24 hours after their preparation.

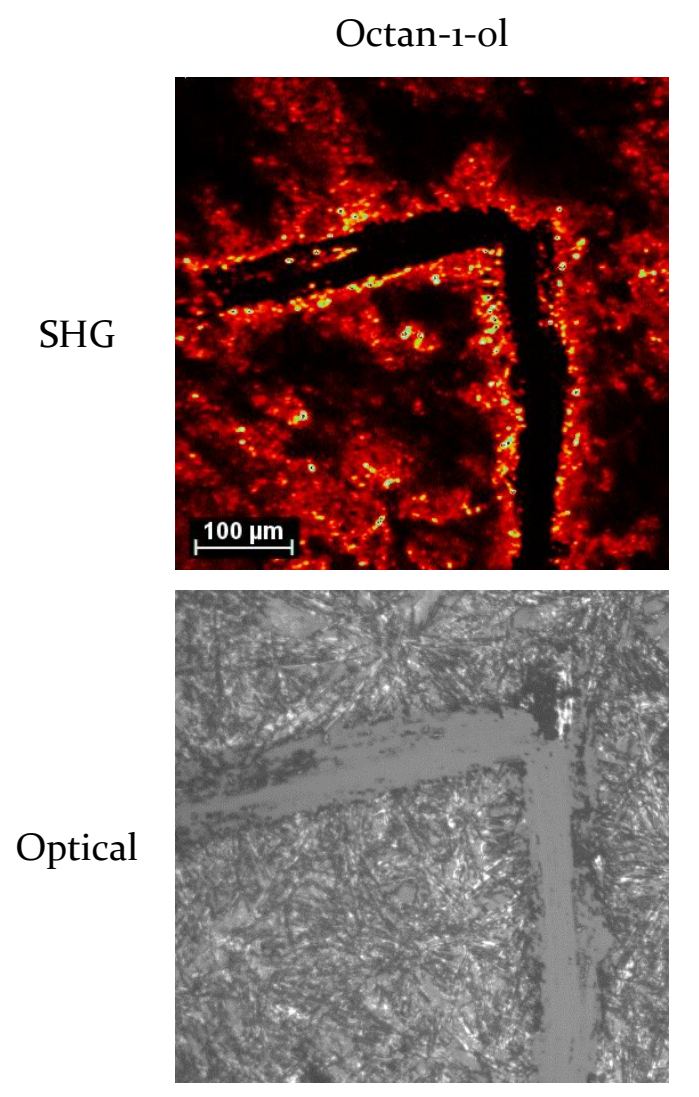

Toluene
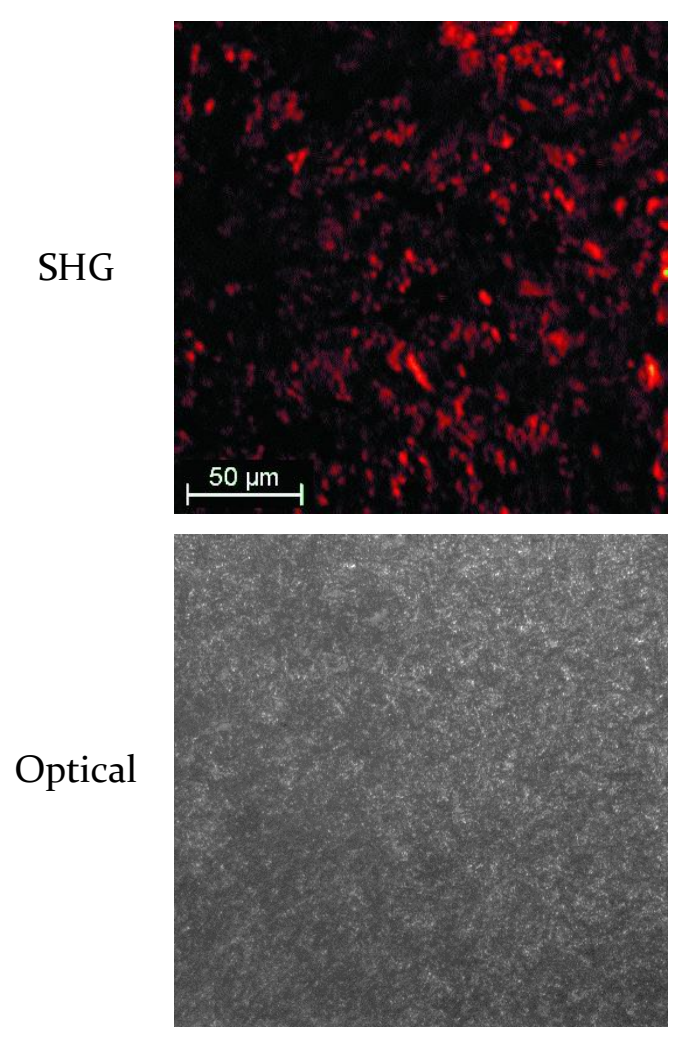

Acetone
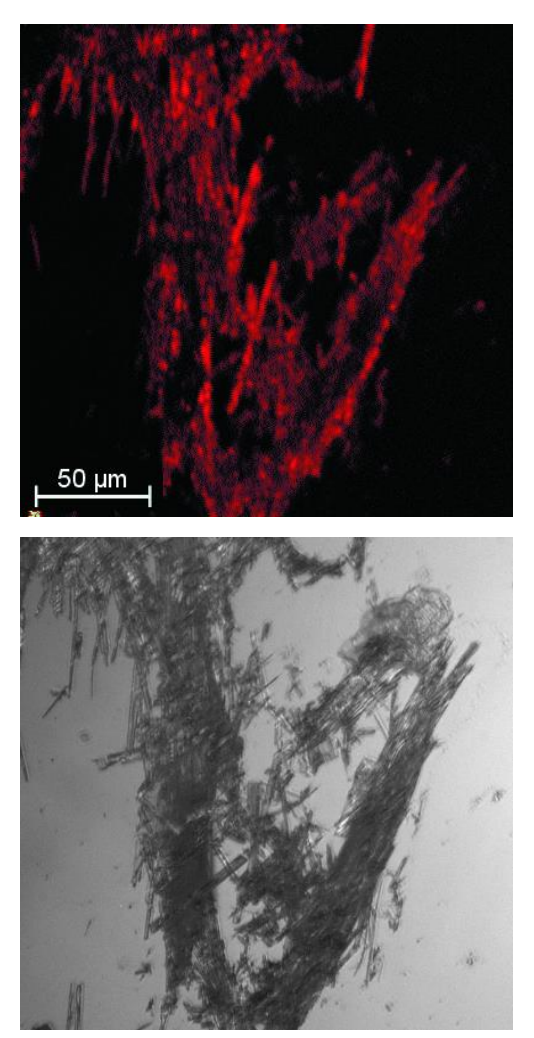

Dioxane
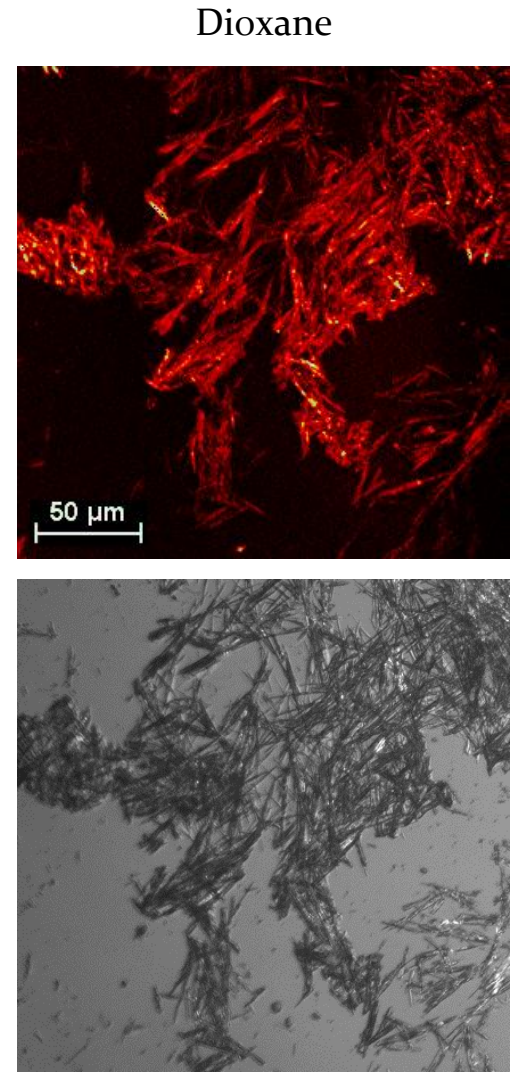

Acetonitrile
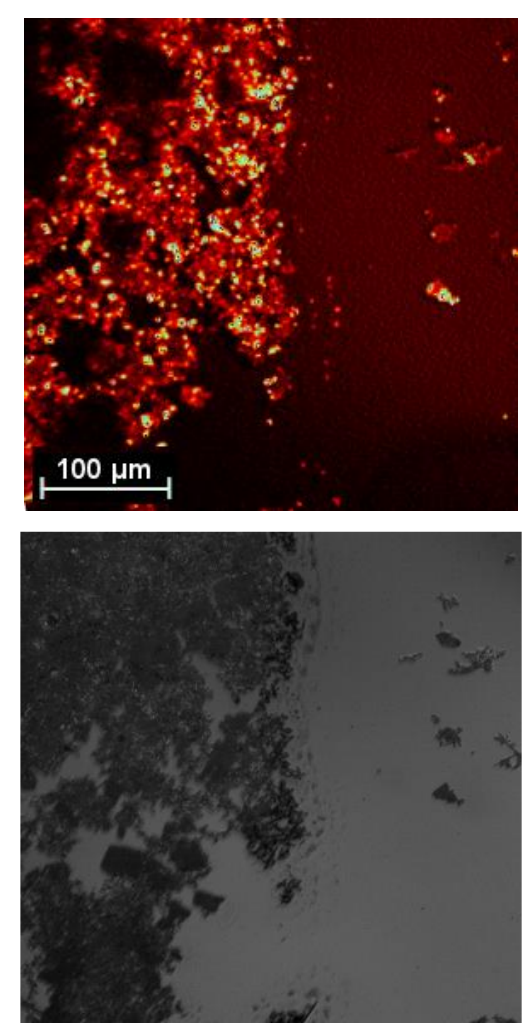

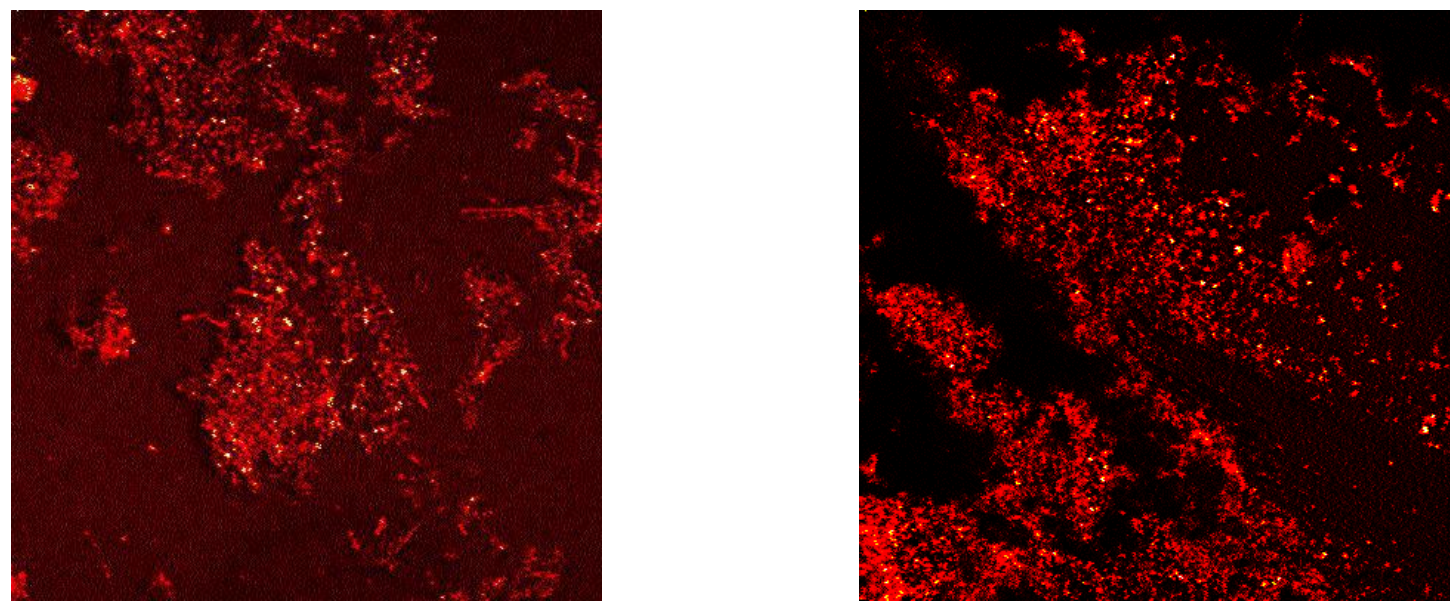

Figure S5. SHG images recorded for xerogels aged for 6 months and prepared from acetonitrile (left) and acetone (right).

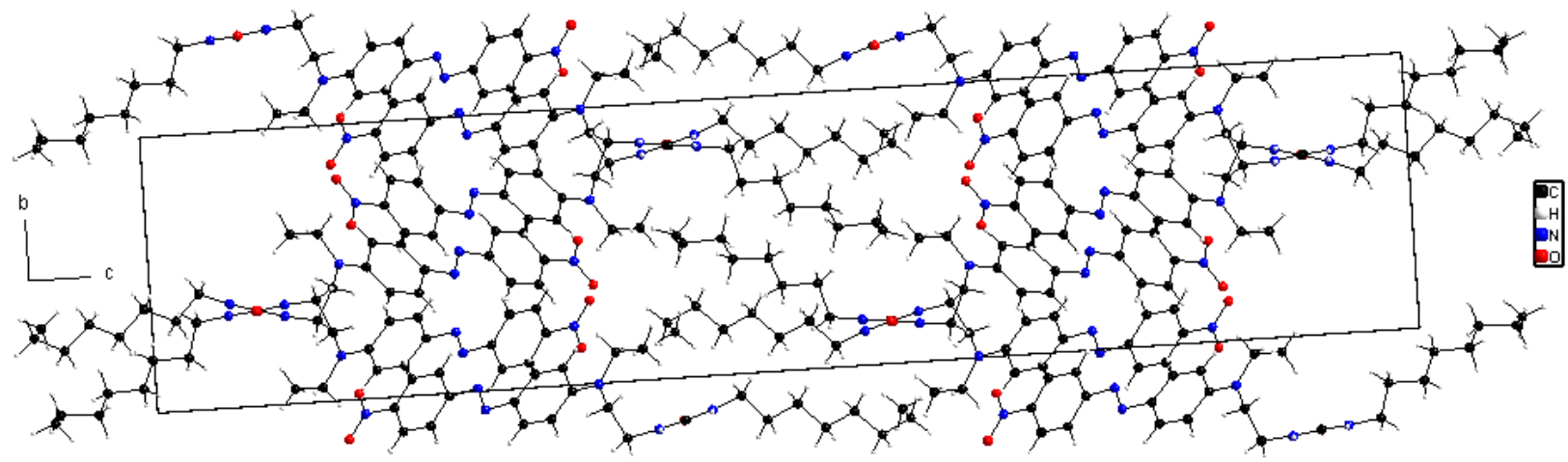

Figure S6. Crystallographic structure of compound $\mathbf{5}$ observed along the a axis.

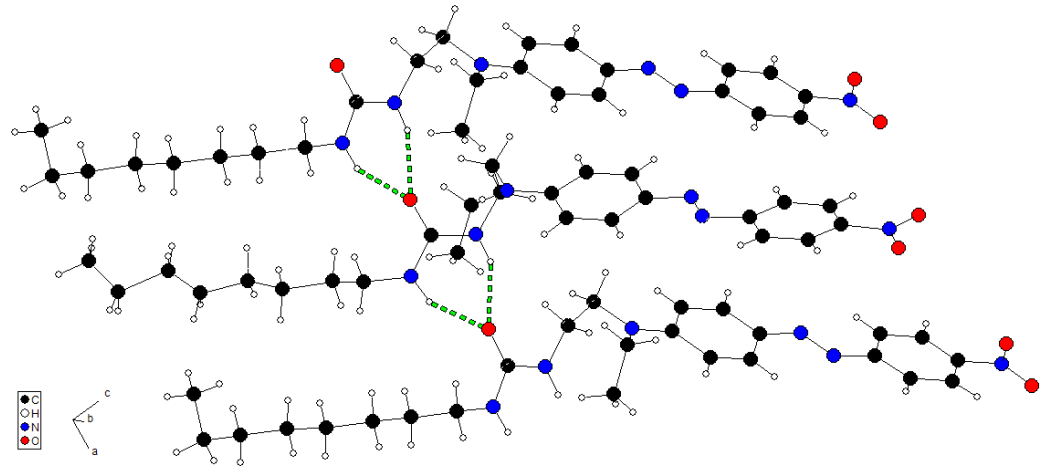

Figure S7. Network of hydrogen bonds observed in the X-ray crystal structure of compound 5 


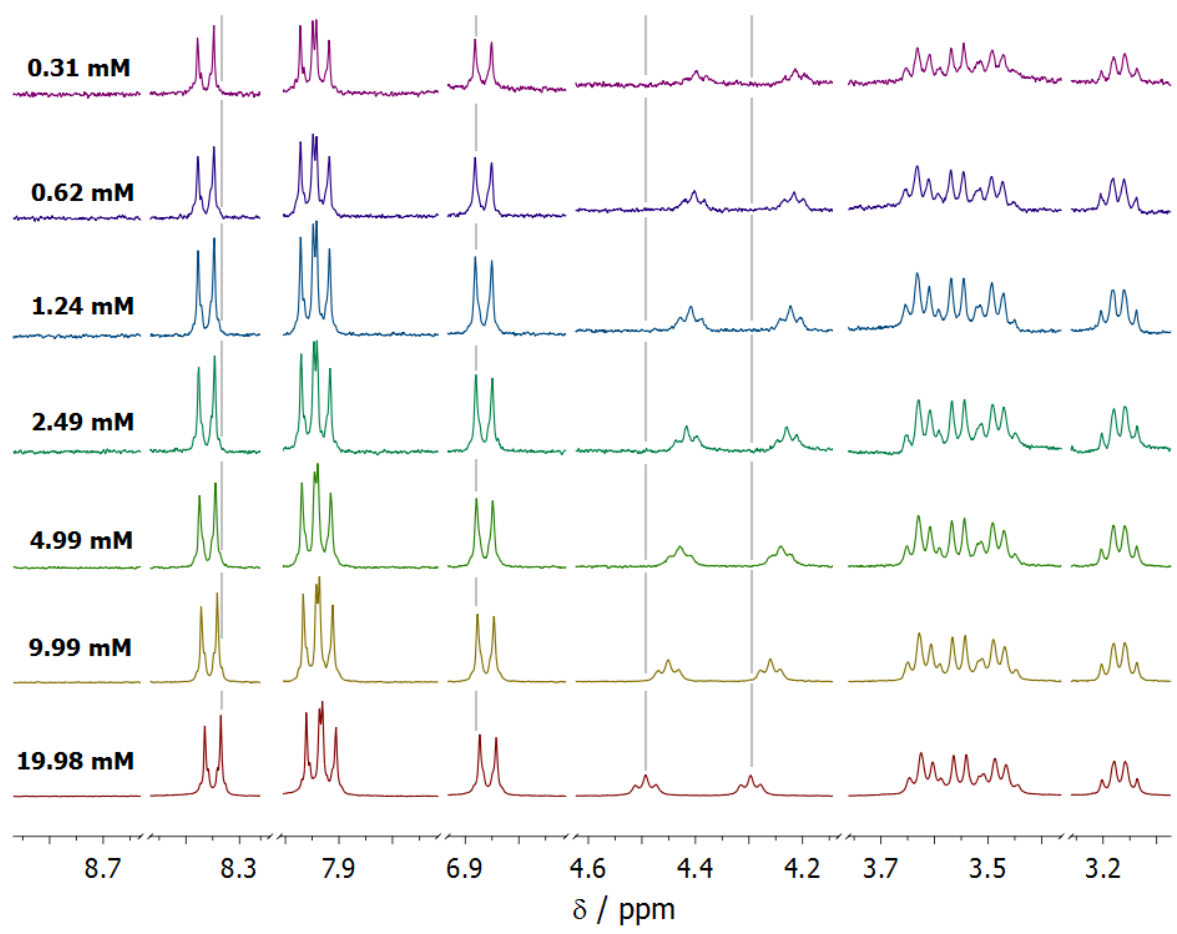

Figure S8. Evolution of the ${ }^{1} \mathrm{H}$ NMR spectrum of compound 1 upon dilution in deuterated chloroform $(298 \mathrm{~K})$

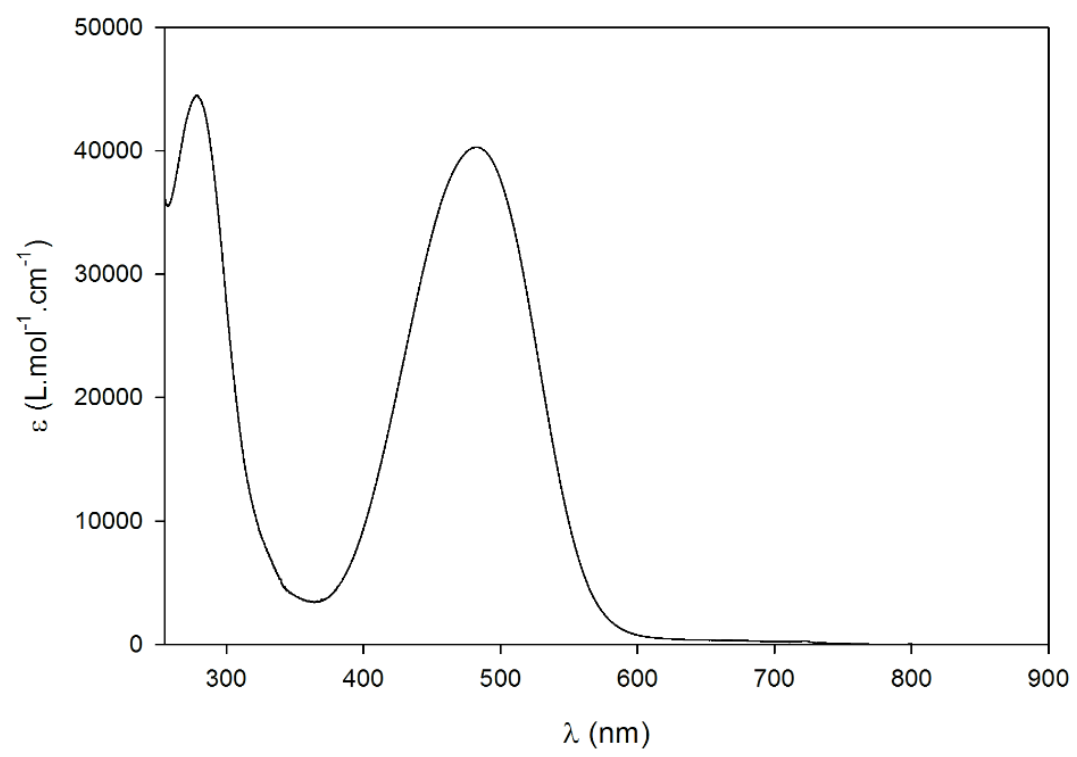

Figure S9. UV-visible absorption spectrum of compound 1, [1] $=10^{-5} \mathrm{~mol} \cdot \mathrm{L}^{-1}, \mathrm{CHCl}_{3}$.

\section{REFERENCES}

(1) Richards, B.; Wolf, E., Proc. R. Soc. London Ser. A 1959, 253, 358.

(2) Zipfel, W. R.; Williams, R. M.; Webb, W. W., Nat. Biotech. 2003, 21, 1369. 